\begin{tabular}{ll}
\hline Saudi Journal of Business and Management Studies (SJBMS) & $\begin{array}{l}\text { ISSN 2415-6663 (Print) } \\
\text { ISSN 2415-6671 (Online) } \\
\text { Scholars Middle East Publishers }\end{array}$ \\
Dubai, United Arab Emirates & \\
Website: http://scholarsmepub.com/ & \\
\hline
\end{tabular}

\title{
The Effectiveness of Local Government Organizing through the Learning Organization Perspective at the Regional Secretariat office of Gorontalo Regency
} Muh Firyal Akbar ${ }^{1}$, Widya Kurniati Mohi ${ }^{1}$

${ }^{1}$ Public Administration, Muhammadiyah University of Gorontalo, Jl. Prof. Dr. H. Mansoer Pateda, Pentadio Timur, Telaga Biru, Gorontalo City, Gorontalo 96181, Indonesia

\begin{tabular}{|c|c|}
\hline $\begin{array}{c}\text { *Corresponding author } \\
\text { Muh Firyal Akbar } \\
\text { Article History } \\
\text { Received: } 01.09 .2018 \\
\text { Accepted: } 08.09 .2018 \\
\text { Published: } 30.09 .2018 \\
\text { DOI: } \\
\text { 10.21276/sjbms.2018.3.9.11 }\end{array}$ & $\begin{array}{l}\text { Abstract: The study aims to analyze the application of learning organizations that are } \\
\text { good to be implemented in government agencies. The specific goal or target for this } \\
\text { research is to obtain comprehensive data related to the effectiveness of the Regional } \\
\text { Government, especially in the Gorontalo Regency Regional Secretariat by using a } \\
\text { learning organization perspective. The type of research used is a qualitative- } \\
\text { quantitative method (Mix Method). The existence of this research can provide clear } \\
\text { information about the effectiveness of the Gorontalo Regional Government in the } \\
\text { learning organization perspective. The results of this study showed an average score } \\
\text { with a high interpretation of all components of learning organization. In addition, the } \\
\text { findings of this study indicate that there is synergy between sections which is } \\
\text { characterized by good communication and coordination between parts, the formation of } \\
\text { the team is situational but still legally written that can facilitate the work of } \\
\text { coordinating with each group member in addition to that there is a process of dialogue } \\
\text { that takes place formally and informally at each structural level that supports the } \\
\text { organizational work climate. However, there are also a number of weaknesses that can } \\
\text { be improved to further optimize the organization of government work in the learning } \\
\text { organization perspective, namely the lack of individual understanding of the vision and } \\
\text { mission needs to be optimized so that organizational performance increases. } \\
\text { Kevwords: Effectiveness, Organizing. Local Government, Learning Organization. }\end{array}$ \\
\hline
\end{tabular}

\section{INTRODUCTION}

An organization that has a commitment to building a strong vision must be able to continue to grow along with the challenges faced. Therefore, a planned effort is needed through the concept of developing organizational capacity that will not be separated from the actions taken by the organization in developing itself within the scope of the organization and specifically the emphasis on individuals within the organization.

Organizational development carried out through interventions at the system, institution and individual levels is a multidimensional effort. Therefore, the planning must be determined in a rational, short-term, medium-term, and long-term stage. Furthermore, at each stage the priorities must be set [1]. In the organization, the behavior of members can be interpreted by each member to each other so that there are interactions that can build the organization well. However, the interactions carried out not only form the organization but also contribute to individuals who are members of the organization [2].

The development of organizational capacity can be derived specifically through a systematic step through the concept of learning organization, which offers a number of systematic problem solving solutions for the organization as an initial activity that optimizes the way used to improve the quality of an organization or as a ways to develop organizational capacity $[3,4]$.

In fact, the tasks at the Regional Secretariat of Gorontalo Regency have not run as expected. The results of observations and loose discussions with the staff in the Gorontalo Regency Secretariat showed that there were several problems in harmonization in completing tasks between existing units or parts. Presented that sometimes there are still many employees who do not really understand the main task of its function, besides that the employees in each unit are still working modestly without any improvisations that can be done in order to increase work effectiveness. Another thing is that some employees do not really know the enthusiasm in achieving the vision and mission of the organization, this can be seen when asking about the details of what vision and mission actually exists in the Gorontalo Regency Secretariat.

Some of the points that become identifiable of the problems that have been described that the researchers will review as an integral part of the 
development of organizational capacity in the Regional Secretariat of Gorontalo Regency so that components such as Personal Mastery, Mental Models, Shared Vision, Team Learning, and Systems Thinking [5] in addition there is an additional component of dialogue [6], it can describe in its entirety the implementation of learning organizations or Learning Organizations at the Regional Secretariat of Gorontalo Regency.

The results of the study will become its own reference to learning organizations within the scope of the Gorontalo Regency Secretariat, research on existing organizational learning or learning organizations has been carried out as done by Farruk [7], researching Learning Organizations and Competitive Advantage-An Integrated Approach, or research conducted by Djonlagic [8], examines the title Developing Learning Organizations for Achievement of Competitive Advantages in Enterprises in Bosnia and Hercegovina. Both of these studies look at learning organizations in the framework of increasing individual capacity, in addition the two studies were conducted in private organizations. Unlike the research that will be conducted that the learning organization is not only in order to increase individual capacity but more broadly because it involves the whole of existing organizations such as systems and others, and learning organization in this study takes the locus of Government agencies.

The purpose of this study is to find out and analyze the effectiveness of the Regional Government, especially in the Gorontalo Regency Regional Secretary using a learning organization perspective, which in turn can be a sustainable reference for research that represents the progress or development of government organizations in Gorontalo Regency.

\section{RESEARCH METHODS}

This study uses descriptive research with qualitative and quantitative approaches (Mix Method), descriptive research is based on the consideration that the data will be obtained more complete, in-depth and reliable and can be found in social contexts. The informants in this study were the Gorontalo Regional Secretary, Assistant 1,2,3 Gorontalo, the Heads of Parts in the Scope of the Gorontalo Regional Secretariat, and the Employees in the Scope of the Gorontalo Regional Secretariat as many as 31 people. The data analysis techniques used to solve problems in this study are qualitative and quantitative descriptive analysis. Qualitative data is obtained starting with reviewing and reviewing all data that has been obtained from various relevant sources, and described in the form of sentences that are logical to draw conclusions. Activities in data analysis are data reduction, data display, and data verification. The mean (average) score is then grouped into three categories (1) Average score:> 3, (2) Medium classified as Average score: 2 - 3 (3) Classified as low ie Average score: $<2$.

\section{RESULTS AND DISCUSSION}

Overall the effectiveness of Local Government organizing in a learning organization perspective at the Regional Secretariat of Gorontalo Regency shows that the research organization studied is based on six components, namely personal mastery, mental model, shared vision, learning team, thinking and dialogue system shows a high overall score and means that the organization of the Regional Government in the perspective of learning organization is carried out effectively. The table of accumulation of all components can be seen in the following table.

\begin{tabular}{|c|c|c|}
\hline Component & Average Score & Interpretation \\
\hline System Thinking & 3,1 & High \\
\hline Personal Mastery & 3,1 & High \\
\hline Model Mentals & 2,9 & Medium \\
\hline Shared Vision & 3,0 & Medium \\
\hline Team Learning & 3,3 & High \\
\hline Dialogue & 3,2 & High \\
\hline Average & $\mathbf{3 , 1}$ & High \\
\hline
\end{tabular}

Source: Processed primary data, 2018.

Based on the interview results, it can be seen that the average score of accumulation of all components of learning organization in the Gorontalo Regency Secretariat is on an average score of 3.1 with a high interpretation indicating that the Local Government's organization in the learning organization perspective is effective but the quantitative interpretation is a number of weaknesses when viewed from the qualitative interpretation presented. The Thinking System component is 3.1 which is included in the high category, then the Personal Mastery component is included in the high category with a score of 3.1 while the Mentals Model component is 2.9 which is included in the medium category. This is a strong indication that the mental component of the model at the Secretariat Gorontalo Regency needs to be improved in order to make the learning organization run effectively.

The Shared Vision component shows the number of 3.0 scores included in the medium category, this shows that improving the behavior and attitudes of individuals in the organization understanding of the Joint Vision needs to be done so that organizational effectiveness in the learning organization perspective in the Regional Secretariat Office of Gorontalo Regency can be optimized. The formation of a solid team can easily complete the work in the high category with an average score of 3.3. The dialogue component has a score of 3.2 which belongs to the high category indicating that the dialogue component has been applied well in organizing the Gorontalo Regency Secretariat.

Some findings that can provide additional explanations of each component are synergies between 
parts which are characterized by good communication and coordination between parts, expressing the needs of certain parts, there will be a system that is collective working, strengths and interpersonal relationships can shape system behavior [5]. This behavior is increasingly controlled by a system that is used to find out work monitoring through Reasonable without Exception (WTP) indicators and Government Institution Performance Accountability Report (LAKIP), besides that, improvements in transparency are further strengthened by the presence of Simda (Regional Management Information System).

In the component of personal expertise that is most mastered is the field of technology. Although in job adaptation requires time to adjust to the work environment. This study also found problems related to personal expertise needs such as expertise needs that were deemed necessary to adjust to the needs of the organization. The process of adapting employees in the execution of tasks requires a process and time to learn to adjust to their main tasks and functions.

In addition there is a discrepancy in the educational background and expertise needed in carrying out the work or assignment given and the adaptability of the State Civil Apparatus (ASN) is absolutely necessary but the obstacle is the long time to adapt, the adaptation process will be easier if ASN has the provision of knowledge and skills that match your work needs.

Interesting phenomenon is also found in the components of mental models (mental models), there are individual habits that can influence the behavior of co-workers so that it can provide a conducive nuance in the work climate of the organization including when individuals experience other work pressures can provide positive treatment for colleagues who face problems or workload that makes him stressful.

There are also cultural influences that influence individual habits such as behavior that is formed due to respect for superiors and disciplines, including contributing positively to the establishment of a business climate, in addition to the behavior of leaders who make mutations that are considered to support the creation of work conditions or a conducive working climate. Furthermore, in the shared vision component, an effort was made by employees at the level of the head of the organization who tried to instill a vision and mission in the organization by disseminating the vision and mission to each section and there were a number of rules that also paid attention to the socialized vision and mission. However, individual understanding of the vision and mission needs to be optimized so that organizational performance is increasing.
The learning component of the team shows that team formation is situational but is still legally written in a way that can facilitate the work of coordinating each group member with collective accountability only in the decision making process a little later than individual decisions. It cannot be denied that in one work group it must be done because it can make the work be directed while the weaknesses have the potential to expect each other to complete the task. The formation of a working group can also make the work more effective, the results are comprehensive, and complete, but the weaknesses in teamwork are a long time to develop a group framework.

In the dialogue component, it is known that there is a dialogue process that takes place both formally and non-formally, while the matters submitted are accommodated and discussed properly so that the decision of the meeting can be submitted to the regent. In addition there is a framework of dialogue that is established between each staff member, section head, and section head who aims if the activity is not yet known and there are problems that do not have a way out of the diologist can provide a space for openness, and new goals to get more effective actions [6]. Another thing that can be observed in this study is the leadership of the regent of Gorontalo where the staff of the Gorontalo Regency secretariat shows how to communicate that safeguards open and democratic dialogue, only in certain situations is dialogue restricted to a disaster situation that requires more direct action.

In the results of the study note that the overall effectiveness of local government organizing in the perspective of learning organization is carried out effectively, but if observed based on the results of the interview search out the findings about the components of system thinking that occur because of the synergy between parts which is characterized by good communication and coordination between parts, expressing needs Part of the system will have a collective work system, in addition there is a system support that is used for work monitoring in the form of indicators for assessing WTP and LAKIP documents. Even monitoring should be carried out with applications not only through document reports [9]. This can be an input for improving system thinking.

Organizing effectiveness observed in the components of system thinking shows that there is synergy between parts with the fields in the Regional Secretariat of Gorontalo Regency, a system that is collective, the progress of the work carried out is supported by an adequate work system, and the ease of updating information on job development is well met. but the inclusion of deep values in the work system still needs to be optimized. Values originating from culture and values held in the organization can help improve a conducive work climate [10]. 
Furthermore, in the aspect of personal expertise there is a discrepancy in the educational background and the skills needed in carrying out the work or assignment given and the adaptive ability of ASN is absolutely necessary but the problem is the length of time to adapt, adaptation can indeed be done but there is a time when the adaptation process must end because can affect organizational work effectiveness [11]. Therefore the thing that must be addressed is the ability of adaptation is also based on the results of research that shows the ability to adapt to various jobs / duties of employees at the Regional Secretariat Office of Gorontalo Regency needs to be improved.

Similarly, cultural influences also influence individual habits that have an impact on work effectiveness [12]. As for the behavior that is formed due to respect for superiors and also discipline which includes giving a positive contribution to the establishment of a business climate besides that the behavior of leaders who make mutations is considered to support the creation of working conditions or a conducive work climate.

Behavior supports the creation of comfortable working conditions fulfilled at the Gorontalo Regency Secretariat Office while the habits of each individual help in developing the organization, anticipating external conditions to maintain organizational excellence, creating a conducive work climate, and individual image influencing the organization's image indicating the need for improvement efforts to make learning organizations run effectively. This is based because there is an influence of the Organizational Climate on Work Productivity [13], this means a conducive work climate is needed so that the organization is effective in achieving its goals.

Efforts are made by employees at the level of the head of the organization who are trying to instill a vision and mission in the organization by socializing the vision and mission in each section and there are a number of rules that also pay attention to the vision and mission that has been socialized. However, individual understanding of the vision and mission needs to be optimized so that organizational performance is increasing.

This study also highlights the socialization of the vision, mission and goals of the organization and understanding of the vision, mission and goals of the organization have been implemented while mutual awareness of the vision and mission of the organization, individual support regarding the achievement of the vision and mission of the organization, and individual equity regarding joint progress within the organization including can still be improved, this shows that improving the behavior and attitudes of individuals in the organization understanding of the Joint Vision needs to be done so that organizational effectiveness in the learning organization perspective in the Regional Secretariat Office of Gorontalo Regency can be optimized. There is a positive relationship between the organization's ability to learn learning organization with the support of achieving the vision and mission of the organization in all components $[14,15]$.

In the learning component of the team shows the habit of being accustomed to working in a working group, a team that is formed effectively to complete the work in sharing knowledge and skills / skills, forming teams familiarizing between personnel / individuals, coordinating the work well, and forming a solid team can easily complete the work including it has been implemented properly. This was also supported by interviews which revealed that the formation of a working group could make work more effective. Team formation is situational but is still legally written in a way that can facilitate the work of coordinating with each group member with collective accountability only in the decision making process a little later than individual decisions. The formation of a working group can also make the work more effective, the results are comprehensive, and complete, but weaknesses in teamwork are a long time for structuring this group framework indicating that organizational learning refers to a process in which the management team changes the model [16].

Through dialogue work makes work easy to do, openness in dealing with problems, achieved goals that are mutually agreed upon, and agreement on work discussions encourages the achievement of organizational goals has been implemented properly. While the discussion of new things being done can still be improved. Overall the dialogue component has been implemented well in organizing the Gorontalo Regency Secretariat. This component of dialogue encourages new ideas to emerge so that organizations need to discuss new ideas, ideas, and knowledge through a learning culture through dialogue and an attitude of respect for emerging thoughts and ideas [6]. This is what is emphasized by Senge [5], to develop an organization requires individuals to continually develop their capacity to create work that increases this can also be obtained through dialogue. There will be no learning organization (LO) without individual learners.

\section{CONCLUSION}

Overall, the effectiveness of Local Government organizing in the learning organization perspective is effectively done based on the average score with a high interpretation of all components of learning organization. In addition, the findings of this study indicate that there is synergy between sections which is characterized by good communication and 
coordination between sections., team formation is situational but is still legally written in order to facilitate the work of coordinating with each group member in addition there is a process of dialogue that takes place formally and informally at each structural level that supports the organizational work climate. However, there are also a number of weaknesses that can be increased to further optimize the organization of government work in the learning organization perspective, namely the lack of individual understanding of the vision and mission needs to be optimized so that organizational performance is increasing, there is a mismatch of educational background and skills needed in carrying out the work or tasks given, the process adaptation will be easier if the state Civil Apparatus (ASN) has provision in the form of knowledge and skills that are in line with work needs

\section{REFERENCES}

1. Ginting, Y., \& Daeli, S. P. (2015). Pengembangan Kapasitas Aparatur Pemerintah Daerah di Era Otonomi (Studi Kasus: Pemerintah Daerah Kabupaten Samosir). Jurnal Bina Praja: Journal of Home Affairs Governance, 4(2), 105-116.

2. Shintaviana, F. V., \& Yudarwati, G. A. (2014). Konsep Diri serta Faktor-faktor Pembentuk Konsep Diri berdasarkan Teori Interaksionisme Simbolik. Online).(uajy. ac. id, diakses 30 Juni 2016).

3. Winter, S. G. (2000). The satisficing principle in capability learning. Strategic management journal, 21(10-11), 981-996

4. Kofman, F., \& Senge, P. M. (1993). Communities of commitment: The heart of learning organizations. Organizational dynamics, 22(2), 523.

5. Senge, P. M. (2014). The fifth discipline fieldbook: Strategies and tools for building a learning organization. Crown Business.

6. Marquardt, M. J. (2011). Building the learning organization: mastering the five elements for corporate learning. Hachette UK.

7. Farrukh, M., \& Waheed, A. (2015). Learning organization and competitive advantage-An integrated approach. Journal of Asian Business Strategy, 5(4), 73.

8. Djonlagic, S., Delic, A., \& KovacevicRahmanovic, A. (2013). Developing learning organizations for achievement of competititive advantegs in enterprises In bosnia and hercegovina. International Conference 2013, Zadar Croatia.

9. Sianturi, B. (2017). Implementasi Algoritma Pattern Matching pada Aplikasi Monitoring Kinerja Dosen Fakultas Teknologi Informasi UKSW (Doctoral dissertation, Program Studi Teknik Informatika FTI-UKSW).

10. Nahruddin, Z., \& Tambajong, H. (2017). The Behavior of Apparatus and Cultural Organization in Provision of Public Service in District Level. Scholars Journal of Arts, Humanities and Social Sciences, 5(7B):716-720.

11. Rahardjo, W. (2005). Peran Faktor-faktor Psikososial dan Keselamatan Kerja pada Jenis Pekerjaan yang Bersifat ISO-STRAIN.

12. Yudhaningsih, R. (2011). Peningkatan efektivitas kerja melalui komitmen, perubahan dan budaya organisasi. Jurnal Pengembangan Humaniora, 11(1), 40-50.

13. Karyana, A. (2012). Pengaruh Iklim Organisasi Terhadap Produktivitas Kerja Di Unit Pelaksana Teknis Kurikulum Kecamatan Jasinga Kabupaten Bogor. Jurnal Organisasi dan Manajemen, 8(1), 67-83.

14. Levinthal, D. A., \& March, J. G. (1993). The myopia of learning. Strategic management journal, 14(S2), 95-112.

15. Etikariena, A., \& Muluk, H. (2014). Correlation between Organizational Memory and Innovative Work Behavior. Hubs-Asia, 9(2), 77-88.

16. Prakoso, B. (2005). Pengaruh Orientasi Pasar, Inovasi Dan Orientasi Pembelajaran Terhadap Kinerja Perusahaan Untuk Mencapai Keunggulan Bersaing (Studi Empiris Pada Industri Manufaktur Di Semarang). Jurnal Studi Manajemen dan Organisasi (JSMO), 2(Nomor 1), 35-57. 